bdellium, myrrh, \&c., are recommended for the cure of cancer of liver, spleen, womb, and other organs. I am, Sir, yours truly,

Harley-street, W., April 6 th. JOHN TWEEDY.

\section{A CASE OF EARLY PREGNANCY.}

To the Editor of THE LANCET.

$\mathrm{SrR},-\mathrm{As}$ the following case appears to me to possess some interest, I am induced to call attention to it. Although there are cases of pregnancy on record as occurring in England at an earlier age than the following, yet the girl in this instance was so extremely young, and parturition proved so unexpectedly easy, that the matter seems worthy of being recorded :-

L, E- (born February 7th, 1867, daughter of a farmer) was brought to me in November last to be treated for amenorrhoea. I learned from her mother that the menstrual flow, which had made its first appearance during the preceding April, had not occurred since. Struck by the peculiar figure of the girl, I inquired of the mother whether she had any suspicion of the nature of her daughter's condition, and I then elicited that it had recently come to the knowledge of the parents that there had been an improper intimacy between her and a lad of twenty, employed as farm servant. In consequence of this I made an examination, which verified my suspicion that she was pregnant. I may here mention that the affair became subsequently the subject of criminal proceedings against the lad, who in January last was sentenced to a term of twelve months' imprisonment under the provisions of the recent Act of Parliament.

Although L. E- was more developed than are most girls of the same age, I naturally anticipated, from her extreme youth, a very tedious if not perilous labour. The sequel will show how agreeably I was disappointed.

On the morning of Feb. 26th I was sent for to visit her, and on reaching the house learned that labour had commenced the previous morning at about half-past ten o'clock. At the time of my arrival $(8.30 \mathrm{~A} . \mathrm{M}$.) I found the os uteri fully dilated and the head presenting in the first position. From that point labour progressed rapidly, and in one hour and a half terminated in the birth of a healthy, well-developed male child. The mother never had a bad symptom, and both she and the child have been doing well since.

It will be seen from the above dates that L. E- was, on the birth of the infant, thirteen years and nineteen days old. I remain, Sir, your obedient servant, AlberT E. MAY, L.R.C.P.Ed., \&e.

Moreton-Hampstead, March 16th, 1880.

\section{THE BEARER CORPS IN SOUTH AFRICA. To the Editor of THE LANCET.}

SIR,-Although it is a matter of very secondary importance to anyone as to which was the first Bearer Company in action in the late war in South Africa, yet as it appears to have been made a matter of moment by Surgeon-Major Scott in his recent letter to THE LANCET (p. 266), I may remark that a regularly-organised company of Kroomen belonging to the Naval Brigade, previously trained by Fleet Surgeon Norbury, R.N., C.B., was in action with that officer at the battle of Inyezane in January, 1879, and besides this, there was also a large number of trained Native Bearers.

I am, Sir, yours faithfully,

John BowDen TrigGs, M.B., Surgeon R.N., In Medical Charge of H.M. Flag-ship Active

during the late war.
Royal Naval Hospital, Cape of Good Hope, March 15th, 1880.

\section{HONORARY QUEEN'S CADETSHIPS.} To the Editor of THE LANCET.

SIR, - There are a certain number of cadetships given every year at Sandhurst, called "honorary Queen's cadetships." These are not to be confounded with "Queen's cadetships." The first-mentioned are boons conferred on officers' sons whose fathers have done good service in the army, and the holders have only to "qualify," and not to "compete," for their commissions. By the warrant these

boons are limited to the sons of the so-called "combatant" officers. The sons of medical officers are excluded from them, no matter what good service their fathers may have done. This is most unjust.-Yours, \&c., March, 1880.

I.V.R.C.

PARIS.

(From our own Correspondent.)

THE proposal to create a new chair of Pathological Anatomy has met with the greatest opposition on the part of the Faculty of Medicine. The professors have all signed a report, which has been sent into the Minister; and they have concluded that the proposed innovation is unnecessary, and that it may be dangerous. It is of course true tha' it is not absolutely necessary to appoint a new professor for this purpose; a post of less importance, such as that of chef des travaux anatomo-pathologiques, might be sufficient, and in this manner the wounded susceptibility of the faculty would be soothed. It is also true that such a precedent might prove dangerous to the interests of the present professors, who have every reason to keep their number as restricted as possible. But as far as teaching is concerned, this report is simply a quibble; some change is greatly needed. At the present time practical morbid anatomy is not taught at all in Paris. Post-mortem examinations are only held at the caprice of the house-surgeons and physicians, and that so irregularly, that a student might pass weeks on the look-out for an autopsy. Paris is not only behind Europe in this respect, but also far behind some of the French provincial schools. At Nancy, autopsies are performed in all cases by a competent pathologist, M. Feltz, the professor of anatomy. In Lyons, similar functions are performed by M. Pierret; and at Lille, by M. Kelsch. There is one reason against the new creation in Paris which, although freely whispered, has not yet been stated. The professor who was designed for the chair by the Minister of Public Instruction, M. Cornil, whose work in connexion with morbid histology is well known, happens to be a member of the Chamber of Deputies. The Faculty of Medicine affects the belief that the whole affair looks very like a job, and is afraid that it would afford a precedent for the future creation of new chairs, to suit the convenience of Ministerial favourites. It will be a great pity if the opposition of the Faculty be allowed to prevail. However the wire-pulling may have been conducted, there can be no doubt that some radical improvement is urgently required.

The Société de Médecine Publique et d'Hygiène Professionelle are going to discuss the proposition of one of their members, Dr. Bourgeois, that the State should take measures to prevent the marriage of individuals suffering from certain hereditary diseases which are most generally transmitted to the offspring. According to Dr. Bourgeois, by the prohibition of such ill-advised alliances, phthisis, epilepsy, and mental disease would soon be exterminated. The commission appointed to examine and report upon the proposition, has, as might be anticipated, concluded against it. In the French law there is only one case in which an individual is incapable of contracting marriage, and that is in the case of an interdit-that is, a person interdicted on account of mental incapacity from the exercise of civil rights, and this is on legal, rather than on hygienic grounds. For a marriage to be legal consent must be given, and as an interdit cannot legally give a valid consent, he cannot contract marriage. Dr. Bourgeois would have every candidate for wedlock submit to medical examination, and would allow marriage to those only who had obtained a medical licence. He also thinks that a difference of twenty-five years between the ages of the two parties should constitute an absolute bar to their union when one of them is over sixty, so that a man of that age would be forbidden to marry a woman of four-and-thirty.

The République Française of this day relates a remarkable freak of nature which has occurred at Cherbourg, and which it copies out of the Vigie de Cherbourg. If the République Française were not al ways of the most respectable prosiness, one might suppose that it was trying to get off what Artemus Ward would call a "goak." The "infant phenomenon" in question is a child, six months old, and the Vigie seems proud that Cherbourg should be privileged to show a marvel 